\title{
Hypoxic induction of atrial natriuretic peptide (factor) secretion An inflammatory interleukin-18 pathway is involved in the control of cardioprotective molecule
}

\author{
Mikko Nikinmaa \\ Department of Biology, University of Turku, Finland

\section{Related article} \\ by Li et al., \\ see p. 972
}

Correspondence to: Prof. Mikko Nikinmaa, MD, PhD,

Department of Biology, University of Turku

Fl-20014 Turku, Finland, phone: +358408361073, e-mail:miknik@utu.fi

Copyright by the Author(s), 2021

Kardiol Pol. 2021 79 (9): 947-948; DOI: $10.33963 /$ KP.a2021.0065

Received: July 9, 2021 Revision accepted: July 12, 2021 Published online: July 12, 2021
In 1985 a seminal article by Lang et al. [1] was published in Nature. It described an atrial factor, which is secreted in response to volume load. This changed the concept of the heart from being just a pump to also being an endocrine organ. The finding of atrial natriuretic peptide (ANP = ANF, atrial natriuretic factor) was followed by the discovery of other cardiac peptides such as brain-type cardiac peptide (BNP), which instead of atria is mainly secreted by ventricles, and C-type cardiac peptide (CNP). In addition, vertebrate groups other than mammals have a different repertoire of peptides. Natriuretic peptides or cardiac peptides (ANP, BNP, and CNP) play a role at least in volume regulation, hemodynamics and the control of heart function. They protect the heart, for example, during ischemia/reperfusion injury. In addition, the diuresis and increasing vascular permeability, which are effects exerted by cardiac peptides, decrease total blood volume. This, in turn, will increase the oxygen-carrying capacity of a unit volume of blood, as a constant number of erythrocytes is in a reduced plasma volume. Thus, cardiac peptides may also function in the control of oxygen transport.

The regulation of ANP secretion has been shown to depend on mechanical stress on the myocytes: the more you stretch the heart, the more pronounced the increase of cardiac peptide secretion is [1, 2]. Also hypoxia, i.e. decreased oxygen level, causes natriuretic peptide release [3]. The best known hypoxic or even anoxic condition of the heart is infarct, but reduced oxygenation in mammals also occurs at high altitudes. Hypoxia is caused by any mismatch between oxygen consumption and blood perfusion of the tissue or the animal: in heart infarct, the perfusion of cardiac cells is reduced because of impaired coronary circulation, at high altitude coronary circulation is not compromised, but the amount of oxygen it contains in a unit volume is decreased. It has initially been considered that also the hypoxia-induced increase in natriuretic peptide secretion would be the result of mechanical stretch occurring in hypoxic cardiac cells. However, accumulating evidence indicates that hypoxia can affect natriuretic peptide release even in the absence of stretch [4] (note that this editorial considers the secretion of both A- and B-type natriuretic peptides to be regulated similarly [5]). In this context, it is notable that virtually all the studies with isolated hearts or cardiac cells have been done with physiological saline, which has the oxygen capacity of ca. 1/30 as compared to blood. Consequently, the cells of perfused hearts may become hypoxic whenever they are, e.g. stretched, making it difficult to differentiate between stretch and hypoxia as the stimuli causing natriuretic peptide release [5]. Furthermore, provided that hypoxia is the stimulus for natriuretic peptide release, isolated heart preparation and the heart in an intact animal may behave differently, since the intact, blood-perfused heart is not experiencing hypoxia in conditions making the isolated heart hypoxic. In addition to the hypoxic increase of natriuretic peptide secretion, also their clearance from the circulation may be affected by hypoxia. There are natriuretic peptide receptors in diverse tissues, and the consensus is that they 
are largely clearance receptors, which decrease in numbers in hypoxia leading to reduced clearance of the peptide.

The regulatory pathway of hypoxia-induced natriuretic peptide secretion has, up to now, remained poorly characterized [6]. It may involve the hypoxia-inducible factor (HIF), and could directly be controlled by it, as the genes encoding natriuretic peptides have hypoxia response elements in their promoter region [7] and as their transcription is increased by HIF [8]. In the current issue of Kardiologia Polska (Polish Heart Journal) Li et al. [9] presented studies showing that the Src-Interleukin-18 (Src-IL-18) pathway regulates ANP production in hypoxic rat atria. Subjecting atria to hypoxic conditions (oxygen tension around $55 \mathrm{~mm}$ $\mathrm{Hg}$ ) they showed that hypoxia upregulated the expression of non-receptor tyrosine kinase Src, causing an increase in the expression of IL-18 and its two receptors through activation of RhoA signaling. The increase in IL-18 was followed by upregulated expression of ATF3, TCF3/LEF1, and TCF4/LEF1, leading to an induction of ANP secretion in hypoxia.

Overall, the effects of the inflammatory cytokine IL18 on the heart are deleterious: it induces myocardial hypertrophy, loss of contractility of cardiomyocytes, and apoptosis leading to myocardial dysfunction [9, 10]. In contrast, those of natriuretic peptides are cardioprotective [3]. This may appear contradictory but is teleologically attractive. Whenever there is an inflammatory heart condition leading to reduced oxygenation in cardiac cells, the very agent, IL-18, involved in the inflammation, will promote natriuretic peptide secretion with a cardioprotective effect.

The whole pathway from hypoxia to IL-18 induction may involve the well-known hypoxic stimulation of ET-1 (endothelin 1) expression, which increases Src expression [9]. Reactive oxygen species (ROS) may be signaling molecules involved [11]. ROS also appear to be behind the ischemia/reperfusion injury: after the ischemic period, reperfusion causes a surge of ROS to the reperfused area. Although the authors did not address the question of whether HIF is involved also in the hypoxia response pathway they describe, this is quite possible. First, HIF is involved in inflammation [12]. Second, HIF is associated with the expression of both ET-1 and Src [13, 14]. Third, although the findings are somewhat controversial, ROS are also involved in the control of HIF [15].

The study by Li et al. [9] helps us in understanding the mechanisms of regulation of natriuretic peptide secretion in a hypoxic heart. Furthermore, as their results connect the deleterious IL-18 with the cardioprotective ANP, the findings have value for the treatment of heart conditions, which are associated with hypoxia. However, up to now, information on the pathways controlling the natriuretic peptide secretion in the hypoxic heart has been delivered in small fragments. Maybe the time would now be right to combine the bits and pieces in order to see the full picture of natriuretic peptide release in hypoxia?

\section{Article information}

Conflict of interest: None declared.

Open access: This article is available in open access under Creative Common Attribution-Non-Commercial-No Derivatives 4.0 International (CC BY-NC-ND 4.0) license, allowing to download articles and share them with others as long as they credit the authors and the publisher, but without permission to change them in any way or use them commercially. For commercial use, please contact the journal office at kardiologiapolska@ptkardio.pl.

How to cite: Nikinmaa M. Hypoxic induction of atrial natriuretic peptide (factor) secretion. An inflammatory interleukin-18 pathway is involved in the control of cardioprotective molecule. Kardiol Pol. 2021; 79(9): 947-948, doi: 10.33963/KP.a2021.0065.

\section{REFERENCES}

1. Lang RE, Thölken $H$, Ganten $D$, et al. Atrial natriuretic factor - a circulating hormone stimulated by volume loading. Nature. 1985; 314(6008): 264-266, doi: 10.1038/314264a0, indexed in Pubmed: 3157062.

2. Ruskoaho H. Atrial natriuretic peptide: synthesis, release, and metabolism. Pharmacol Rev. 1992; 44(4): 479-602, indexed in Pubmed: 1480667.

3. Arjamaa $\mathrm{O}$, Nikinmaa M. Hypoxia regulates the natriuretic peptide system. Int J Physiol Pathophysiol Pharmacol. 2011; 3(3): 191-201, indexed in Pubmed: 21941610.

4. Arjamaa O, Vuolteenaho O, Kivi E, et al. Hypoxia increases the release of salmon cardiac peptide ( $\mathrm{SCP}$ ) from the heart of rainbow trout (Oncorhynchus mykiss) under constant mechanical load in vitro. Fish Physiol Biochem. 2014; 40(1): 67-73, doi: 10.1007/s10695-013-9824-4, indexed in Pubmed: 23813187.

5. Anttila K, Streng T, Pispa J, et al. Hypoxia exposure and B-type natriuretic peptide release from Langendorff heart of rats. Acta Physiol (Oxf). 2017; 220(1): 28-35, doi: 10.1111/apha.12767, indexed in Pubmed: 27496203.

6. Arjamaa O, Nikinmaa M. Natriuretic peptides in hormonal regulation of hypoxia responses. Am J Physiol Regul Integr Comp Physiol. 2009; 296(2): R257-R264, doi: 10.1152/ajpregu.90696.2008, indexed in Pubmed: 19005014.

7. Chun YS, Hyun JY, Kwak YG, et al. Hypoxic activation of the atrial natriuretic peptide gene promoter through direct and indirect actions of hypoxia-inducible factor-1. Biochem J. 2003; 370(Pt 1): 149-157, doi: 10.1042/BJ20021087, indexed in Pubmed: 12413399.

8. Weidemann A, Klanke B, Wagner M, et al. Hypoxia, via stabilization of the hypoxia-inducible factor HIF-1alpha, is a direct and sufficient stimulus for brain-type natriuretic peptide induction. Biochem J. 2008; 409(1): 233-242, doi: 10.1042/BJ20070629, indexed in Pubmed: 17822384.

9. Li X, Wei CX, Wu CZ, et al. SrC-IL-18 signaling regulates the secretion of atrial natriuretic factor in hypoxic beating rat atria. Kardiol Pol. 2021; 79(9): 972-979, doi: 10.33963/KP.a2021.0051, indexed in Pubmed: 34176112.

10. DoiT,Sakoda T, Akagami T, etal. Aldosterone induces interleukin-18through endothelin-1, angiotensin II, Rho/Rho-kinase, and PPARs in cardiomyocytes. Am J Physiol Heart Circ Physiol. 2008; 295(3): H1279-H1287, doi: 10.1152/ajpheart.00148.2008, indexed in Pubmed: 18660453.

11. Wu CZ, Li X, Hong $L$, et al. NOX4/SrC regulates ANP secretion through activating ERK1/2 and Akt/GATA4 signaling in beating rat hypoxic atria. Korean J Physiol Pharmacol. 2021; 25(2): 159-166, doi: 10.4196/kjpp.2021.25.2.159, indexed in Pubmed: 33602886.

12. Imtiyaz HZ, Simon MC. Hypoxia-inducible factors as essential regulators of inflammation. Curr Top Microbiol Immunol. 2010; 345: 105-120, doi: 10.1007/82_2010_74, indexed in Pubmed: 20517715.

13. Tipoe GL, Lau TYH, Nanji AA, et al. Expression and functions of vasoactive substances regulated by hypoxia-inducible factor-1 in chronic hypoxemia. Cardiovasc Hematol Agents Med Chem. 2006; 4(3): 199-218, doi: 10.2174/187152506777698290, indexed in Pubmed: 16842206.

14. Liu P, Gu Y, Luo J, et al. Inhibition of SrC activation reverses pulmonary vascular remodeling in experimental pulmonary arterial hypertension via Akt/mTOR/HIF-1 signaling pathway. Exp Cell Res. 2019; 380(1):36-46, doi: 10.1016/j.yexcr.2019.02.022, indexed in Pubmed: 30802452.

15. Görlach A, Kietzmann T. Superoxide and derived reactive oxygen species in the regulation of hypoxia-inducible factors. Methods Enzymol. 2007; 435: 421-446, doi: 10.1016/S0076-6879(07)35022-2, indexed in Pubmed: 17998067. 